\title{
Gender differences in mortality in patients with ST-segment elevation myocardial infarction
}

\author{
Diferencias de género en la mortalidad en pacientes con infarto de miocardio con \\ elevación del segmento ST
}

\author{
Grecia I.M. Raymundo-Martínez ${ }^{1 *}$, Diego Araiza-Garaygordobi2, Rodrigo Gopar-Nieto', \\ Arnoldo E. Loáisiga-Sáenz¹, Luis A. Baeza-Herrera1, Ricardo Pohls-Vázquez", Laura V. Torres-Araujo', \\ Manuel Martínez-Ramos Méndez ${ }^{1}$, Arturo I. Alonso ${ }^{3}$, Itzel V. Delgado-Cruz ${ }^{3}$, \\ Diestefano E. Ronquillo-Ramírez ${ }^{3}$, and Alexandra Arias-Mendoza²
}

${ }^{1}$ Cardiology Fellow, National Institute of Cardiology Ignacio Chávez, Mexico City, Mexico; ${ }^{2}$ Department of Coronary Care Unit and Emergency, National Institute of Cardiology Ignacio Chávez, Mexico City, Mexico; ${ }^{3}$ Research fellow. National Institute of Cardiology Ignacio Chávez, Mexico City, Mexico

\begin{abstract}
Objective: Women with ST-segment elevation myocardial infarction (STEMI) have worst outcomes than men. The objective of the study was to determine gender differences in mortality in patients with STEMI. Methods: Cohort study including patients with STEMI. We recorded demographic and clinical data, laboratory tests, and in-hospital mortality in patients who underwent primary angioplasty and pharmacoinvasive strategy. Kaplan-Meier analysis was used to assess mortality differences between both genders. Results: A total of 340 patients were analyzed, 296 males and 44 females. Mean age of the female group was $64.3 \pm 12.3$ years. About $98 \%$ of females were among Killip-Kimball Class I-II. They had higher risk scores compared to man, longer ischemic time and first medical contact with a difference in comparison to man of 47 and 60 min, respectively. Mortality was $9.1 \%$ (4) in the female group. Conclusions: Although the proportion of women had higher mortality than man, we did not found any difference with statistical significance probably due to the lack of representation. We need more awareness in the female population about STEMI, since longer first medical contact time and longer total ischemic time might be one possible explanation of a higher mortality.
\end{abstract}

Key words: Myocardial infarction. Gender difference. ST-segment elevation myocardial infarction. Mortality.

\section{Resumen}

Objetivo: Las mujeres con infarto agudo al miocardio con elevación del segmento ST (SICA CEST) tienen peor pronóstico que Ios hombres. El objetivo fue determinar las diferencias de mortalidad en género en pacientes con SICA CEST. Metodos: Estudio de cohorte de pacientes con SICA CEST. Se recolectaron datos demográficos, clínicos, de laboratorio y mortalidad intrahospitalaria. Se realizó un análisis de Kaplan-Meier para valorar la mortalidad y determinar diferencias de género. Resultados: Se analizaron 340 pacientes, 296 hombres y 44 mujeres. Se observó que las mujeres tuvieron mayores puntajes en los scores de riesgo, mayor tiempo de primer contacto y tiempo total de isquemia encontrando una diferencia con el grupo de hombres de 47 y 60 minutos respectivamente. La mortalidad intrahospitalaria fue de $9.1 \%$ (4) sin diferencia estadísticamente significativa

\section{Correspondence:}

*Grecia I.M. Raymundo-Martínez E-mail: graymundo87@gmail.com 2604-7063 / C 2020 Instituto Nacional de Cardiología Ignacio Chávez. Published by Permanyer. This is an open access article under the CC BY-NC-ND license (http://creativecommons.org/licenses/by-nc-nd/4.0/).
Date of reception: 16-04-2020

Date of acceptance: 06-10-2020
Available online: 12-11-2020 Arch Cardiol Mex (Eng). 2021;91(3):266-273 www.archivoscardiologia.com 
en comparación con los hombres. Conclusiones: Aunque la proporción de mujeres tuvo mayor mortalidad no se encontró diferencia estadísticamente significativa en comparación con los hombres probablemente por el tamaño de la muestra debido a baja representación del grupo femenino. Se necesita mayor conciencia en relación al infarto en el grupo de mujeres, ya que mayor tiempo de primer contacto y mayor tiempo total de isquemia pueden ser una posible explicación de una mayor mortalidad.

Palabras clave: Infarto agudo al miocardio. Diferencia de género. SICA CEST. Mortalidad.

\section{Introduction}

Ischemic heart disease represents the primary cause of death in Mexico ${ }^{1-5}$, mostly attributed to acute myocardial infarction. Women have been underrepresented in most trials regarding ischemic heart disease and it is well known that women have risk factors of their own, which makes it questionable to say that treatment tested is as effective in this group, because differences in survival and mortality have been significantly different through the years. Globally, coronary artery disease has been more prevalent in women than in men. Around the world, the mean age of presentation of myocardial infarction in women is 64.5 years of age, and it carries a worst prognosis. Those who have a first event before the age of 50 double the risk of mortality compared to men $^{1-3,6-10}$. Bowles et al. acknowledged that women in his study did not attribute cardiovascular symptoms to ST-segment elevation myocardial infarction (STEMI), but to extracardiac cause ${ }^{10}$. As we know, timely reperfusion for STEMI carries better outcomes. Pharmacoinvasive strategy (PS) has proven in several clinical trials to be as effective as primary percutaneous coronary intervention (PPCl) especially when is implemented in places were demographic and socioeconomics represent an issue when it comes to perform $\mathrm{PPCl}$. Even though PS is equally effective than $\mathrm{PPCl}$, women keep having higher mortality rates. The national program for the reduction of mortality in STEMI carried out by health department and by the National Heart Institute in Mexico, revealed that 8 out of every 19 patients did not have information regarding STEMI, and only one-third of females had a correct identification of symptoms. Interviewed women had less knowledge or wrong concept of STEMI. Most women did acknowledge that they would search for medical attention if having an event, but this does not correlate to the real world because the first medical contact for women tends to be higher than men ${ }^{11}$. There is a high percentage of death in women than in men, being consistently higher in every age group, even when the cases are more frequent in men ${ }^{11}$. For this reason, the aim of this study was to determine the differences in gender and outcomes in patients with STEMI in the Mexican population who were taken either to $\mathrm{PS}$ or $\mathrm{PPCl}$ within the PHASE-MX registry ${ }^{12}$.

\section{Methods}

A cohort from the PHASE-MX trial was taken, which included patients with both genders, between 18 and 80 years of age, with a diagnosis of STEMI, that were admitted in the Emergency Department and Coronary Care Unit of the National Heart Institute Ignacio Chavez from April 1 of 2018 to March 31 of 2019. The area of care and reference of the Mexico City metropolitan area comprise a calculated area of $7954 \mathrm{~km}^{2}$, with a population of 20.4 million inhabitants. Patients from 60 hospitals from the metropolitan area were received. At admission, the following data were collected: age, gender, date of admission, the presence of diabetes mellitus, systemic arterial hypertension, smoking, chronic kidney disease, obesity, previous history of myocardial infarction, previous revascularization, vital signs, TIMI, GRACE and CRUSADE scores, blood biometrics, blood glucose, troponin, NT proBNP, total ischemic time, first medical contact time, door-to-needle time, door-to-wire crossing or device time, medical treatment before reperfusion, time to PS, and treatment success. In-hospital follow and date of home discharge were registered.

\section{Statistical analysis}

STATA v13 (StataCorp LP, College Station, Tx) was used. Quantitative variables were analyzed with descriptive methods depending on their normality, corroborated by the Shapiro-Wilk test. Parametric variables were described with mean value and standard deviation. In the case of non-parametric variables, median and interquartile ranges were used. Likewise, taking into consideration, the normality of each quantitative variable, an analysis with Student's t-test and MannWhitney U-test was performed. Qualitative variables were described through frequencies and percentages, while for the bivariate analysis, the $\chi^{2}$ or the Fisher's test was performed depending on the number of events. Cox regression models were built to find association 
Table 1. Demographic characteristics in patients with STEMI and comparison of those taken to PS versus PCI

\begin{tabular}{|c|c|c|c|c|c|c|c|}
\hline \multirow[t]{2}{*}{ Variable } & \multicolumn{2}{|c|}{ Total $(n=340)$} & \multicolumn{2}{|c|}{ PS $(n=166)$} & \multicolumn{2}{|c|}{ PCI $(n=174)$} & \multirow[t]{2}{*}{$\mathbf{p}$} \\
\hline & $\mathbf{n}$ & $\%$ & n & $\%$ & $n$ & $\%$ & \\
\hline Male & 296 & 87.1 & 148 & 89.2 & 148 & 85.1 & \multirow[t]{2}{*}{0.26} \\
\hline Female & 44 & 12.9 & 18 & 10.8 & 26 & 14.9 & \\
\hline Diabetes mellitus & 119 & 35 & 58 & 34.9 & 61 & 35.1 & 0.98 \\
\hline Systemic arterial hypertension & 159 & 46.8 & 72 & 43.4 & 87 & 50 & 0.22 \\
\hline Dyslipidemia & 58 & 17.1 & 21 & 12.7 & 37 & 21.3 & 0.03 \\
\hline Current smoking & 157 & 46.2 & 88 & 53 & 69 & 39.7 & 0.01 \\
\hline Ceased smoking & 56 & 16.5 & 23 & 13.9 & 33 & 18.97 & 0.2 \\
\hline Chronic kidney disease & 7 & 2.1 & 4 & 2.4 & 3 & 1.72 & 0.47 \\
\hline Obesity & 77 & 22.7 & 35 & 21.1 & 42 & 24.1 & 0.50 \\
\hline Previous myocardial infarction & 33 & 9.7 & 14 & 8.4 & 19 & 10.9 & 0.43 \\
\hline Previous $\mathrm{PCl}$ & 23 & 6.8 & 7 & 4.3 & 16 & 9.2 & 0.05 \\
\hline Previous CABG & 5 & 1.5 & 1 & 0.6 & 4 & 2.3 & 0.20 \\
\hline Heart failure & 3 & 0.9 & 0 & 0 & 3 & 1.7 & 0.08 \\
\hline Valvular heart disease & 2 & 0.6 & 0 & 0 & 2 & 1.2 & 0.26 \\
\hline \multirow[t]{2}{*}{ Atrial fibrillation } & 1 & 0.3 & 0 & 0 & 1 & 0.6 & 0.32 \\
\hline & $\mathbf{n}$ & Mean \pm SD & $\mathbf{n}$ & Mean \pm SD & n & Mean \pm SD & $\mathbf{p}$ \\
\hline Age (years) & 340 & $59 \pm 10.8$ & 166 & $58.5 \pm 10.9$ & & $60 \pm 11$ & 0.08 \\
\hline
\end{tabular}

PS: pharmacoinvasive strategy; PCI: percutaneous coronary intervention; CABG: coronary artery bypass grafting; SD: standard deviation. STEMI: ST-segment elevation myocardial infarction.

between risk factors and mortality (dependent variable) in patients treated with both strategies. For the survival analysis, tables and Kaplan-Meier curves were made to describe mortality in both groups. $p<0.05$ was considered as statistically significant.

\section{Results}

A total of 340 patients were analyzed, 296 males and 44 females (Table 1). Mean age of the female group was $64.3 \pm 12.3$ years. Among the female group, $56.8 \%$ had diabetes mellitus, $50.1 \%$ had systemic arterial hypertension, $5.9 \%$ had dyslipidemia, $18.2 \%$ actively smoking, $2.3 \%$ had chronic kidney disease, $15.9 \%$ had obesity, $11.4 \%$ had previous myocardial infarction, $9.7 \%$ had previous percutaneous coronary intervention, $2.3 \%$ had previous coronary artery bypass graft, $2.3 \%$ had some sort of valvular heart disease, and $2.3 \%$ had heart failure. There were no cases with atrial fibrillation (Table 2).
At arrival, $98 \%$ of females were among Killip-Kimball Class I-II. The mean heart rate was $77 \mathrm{bpm}$, mean respiratory rate was $18 \mathrm{bpm}$, mean systolic arterial pressure was $116 \mathrm{mmHg}$, mean diastolic arterial pressure was $71.5 \mathrm{mmHg}$, and mean pulse oximetry was $92 \%$. As far as clinical risk scores, mean TIMI score was 5 points, mean GRACE score was 146.5 points, and mean CRUSADE score was 39.5 points with statistically significant difference compared to men (Table 3).

Within the laboratory evaluation at arrival in the women's group, the mean hemoglobin was $14.2 \mathrm{~g} / \mathrm{dl}$, mean creatinine was $0.84 \mathrm{~g} / \mathrm{dl}$, mean urea nitrogen was $19.2 \mathrm{mg} / \mathrm{dl}$, mean leukocytes was $10.7 \times 10^{\star 3} \mu \mathrm{L}$, and NT proBNP value was significantly higher than men, 1750 versus $688(p=0.00)$, respectively. Initial and maximal troponin levels did not show statistical difference compared to men. Mean serum glucose in the women's group was $193.5 \mathrm{mg} / \mathrm{dl}$ being significantly higher than men whom mean value was $156 \mathrm{mg} / \mathrm{dl}$ $(p=0.01)$, and this was reflected in the glycated 
Table 2. Demographic data at arrival of patients with STEMI

\begin{tabular}{|c|c|c|c|c|c|c|c|}
\hline \multirow[t]{2}{*}{ Variable } & \multicolumn{2}{|c|}{ Total $(n=340)$} & \multicolumn{2}{|c|}{ Male $(n=296)$} & \multicolumn{2}{|c|}{ Female $(n=44)$} & \multirow[t]{2}{*}{$\mathbf{p}$} \\
\hline & n & $\%$ & $\mathbf{n}$ & $\%$ & $\mathbf{n}$ & $\%$ & \\
\hline Diabetes mellitus & 119 & 35 & 94 & 31.8 & 25 & 56.8 & $0.00^{*}$ \\
\hline Systemic arterial hypertension & 159 & 46.8 & 133 & 44.9 & 26 & 59.1 & $0.07^{*}$ \\
\hline Dyslipidemia & 58 & 17.1 & 51 & 17.2 & 7 & 15.9 & $0.82^{*}$ \\
\hline Current smoking & 157 & 46.2 & 149 & 50.3 & 8 & 18.2 & $0.00^{*}$ \\
\hline Ceased smoking & 56 & 16.5 & 50 & 16.9 & 6 & 13.6 & $0.58^{*}$ \\
\hline Chronic kidney disease & 7 & 2.1 & 6 & 2 & 1 & 2.3 & $0.62^{*}$ \\
\hline Obesity & 77 & 22.7 & 70 & 23.7 & 7 & 15.9 & $0.25^{*}$ \\
\hline Previous myocardial infarction & 33 & 9.7 & 28 & 9.5 & 5 & 11.4 & $0.69^{*}$ \\
\hline Previous $\mathrm{PCl}$ & 23 & 6.8 & 19 & 6.4 & 4 & 9.1 & $0.34^{*}$ \\
\hline Previous CABG & 5 & 1.5 & 4 & 1.4 & 1 & 2.3 & $0.50^{*}$ \\
\hline Heart failure & 3 & 0.9 & 2 & 0.7 & 1 & 2.3 & $0.29^{*}$ \\
\hline Valvular heart disease & 2 & 0.6 & 1 & 0.3 & 1 & 2.3 & $0.24^{*}$ \\
\hline Atrial fibrillation & 1 & 0.3 & 1 & 0.3 & 0 & 0 & $0.69^{*}$ \\
\hline & n & Mean \pm SD & n & Mean \pm SD & n & Mean \pm SD & $\mathbf{p}$ \\
\hline Age (years) & 340 & $59 \pm 10.8$ & 296 & $58.3 \pm 10.4$ & 44 & $64.3 \pm 12.3$ & $0.00+$ \\
\hline
\end{tabular}

PCI: percutaneous coronary intervention; CABG: coronary artery bypass grafting; SD: standard deviation. ${ }^{*}$ Chi squared, +Student's t-test (independent). STEMI: ST-segment elevation myocardial infarction.

Table 3. Vital signs and risk scores at admission in patients with STEMI

\begin{tabular}{|c|c|c|c|c|c|c|c|}
\hline \multirow[t]{2}{*}{ Variable } & \multicolumn{2}{|c|}{ Total $(n=340)$} & \multicolumn{2}{|c|}{ Male ( $n=296$ ) } & \multicolumn{2}{|c|}{ Female $(n=44)$} & \multirow[t]{2}{*}{$\mathbf{p}$} \\
\hline & $\mathbf{n}$ & $\%$ & $\mathbf{n}$ & $\%$ & $\mathbf{n}$ & $\%$ & \\
\hline Killip-Kimball I & 181 & 54.4 & 160 & 55.4 & 21 & 47.7 & \multirow[t]{4}{*}{$0.36^{*}$} \\
\hline Killip-Kimball II & 132 & 39.6 & 111 & 38.4 & 21 & 47.7 & \\
\hline Killip-Kimball III & 10 & 3 & 8 & 2.8 & 2 & 4.6 & \\
\hline \multirow{2}{*}{ Killip-Kimball IV } & 10 & 3 & 10 & 3.5 & 0 & 0 & \\
\hline & $\mathbf{n}$ & Median (IOR) & $\mathbf{N}$ & Median (IOR) & $\mathbf{n}$ & Median (IOR) & p \\
\hline Heart rate (bpm) & 340 & $75.5(68.5-90)$ & 296 & $75(67-90)$ & 44 & $77(70-92.5)$ & 0.66 \\
\hline Respiratory rate (rpm) & 340 & $18(16-19)$ & 296 & $18(16-19)$ & 44 & $18(16-19.5)$ & 0.70 \\
\hline Systolic arterial pressure $(\mathrm{mmHg})$ & 340 & $127(114-147)$ & 296 & $130(117-146)$ & 44 & $116(106-157)$ & 0.07 \\
\hline Diastolic arterial pressure $(\mathrm{mmHg})$ & 340 & $80(70-90)$ & 296 & $80(70-90)$ & 44 & $71.5(64.5-82.5)$ & 0.01 \\
\hline Pulse oximetry (\%) & 340 & $92(90-95)$ & 296 & $92(90-95)$ & 44 & $92(90-94)$ & 0.58 \\
\hline TIMI score & 340 & $4(2-5)$ & 296 & $3(2-5)$ & 44 & $5(3-7)$ & 0.00 \\
\hline GRACE score & 340 & $125(101-150)$ & 296 & $123(100-147)$ & 44 & $146.5(110-164.5)$ & 0.02 \\
\hline CRUSADE score & 340 & $26(18-35)$ & 296 & $25(18-33)$ & 44 & $39.5(27.5-55)$ & 0.00 \\
\hline
\end{tabular}

IQR: interquartile range. *Chi cuadrado. STEMI: ST-segment elevation myocardial infarction. 
Table 4. Laboratory findings in patients with STEMI

\begin{tabular}{|c|c|c|c|c|}
\hline Variable & Total $(\mathrm{n}=340)$ Median (IOR) & Male $(\mathrm{n}=296)$ Median (IOR) & Female ( $n=44$ ) Median (IOR) & $\mathbf{p}$ \\
\hline Hemoglobin $(\mathrm{g} / \mathrm{L})$ & $15.6(14.4-16.7)$ & $15.8(14.6-16.8)$ & $14.2(12.9-15.5)$ & 0.00 \\
\hline Creatinine (mg/dL) & $1(0.8-1.2)$ & $1(0.8-1.2)$ & $0.84(0.7-1.1)$ & 0.01 \\
\hline Urea nitrogen $(\mathrm{mg} / \mathrm{dL})$ & $17(14-23)$ & $17(14-22)$ & $19.2(14.9-32)$ & 0.03 \\
\hline Sodium & 136 (134-138) & $136(134-138)$ & $135(133-137.5)$ & 0.44 \\
\hline C-reactive protein & $6.9(2.7-28.7)$ & $6.6(2.6-31.9)$ & $12(3.8-21.4)$ & 0.38 \\
\hline Leukocytes & $11.7(9.3-14.4)$ & $11.9(9.5-14.7)$ & $10.7(7.9-12.9)$ & 0.01 \\
\hline NT proBNP & $793.5(222.5-3284.5)$ & $688(194-2958)$ & $1750(615-4373)$ & 0.00 \\
\hline Troponin I & $12.7(0.9-52.8)$ & $12.8(0.9-52.3)$ & $14.1(1.2-56.4)$ & 0.77 \\
\hline Maximum troponin I & $64(24-80)$ & $63.4(23.9-80)$ & $74.6(26-80)$ & 0.41 \\
\hline Serum glucose $(\mathrm{mg} / \mathrm{dL})$ & $162.5(1278-238.5)$ & $156(125-230)$ & $193.5(140-280)$ & 0.01 \\
\hline K & $4.1(3.8-4.4)$ & $4.1(3.8-4.4)$ & $4.1(3.8-4.6)$ & 0.53 \\
\hline $\mathrm{Cl}$ & $103(100-105.52)$ & $103(100-105.1)$ & $104(100-107)$ & 0.33 \\
\hline Glycated hemoglobin & $6.1(5.65-8.2)$ & $6.1(5.6-7.6)$ & $7.7(5.9-9.5)$ & 0.00 \\
\hline Albumin & $3.6(3.3-3.9)$ & 3.7 (3.4-3.9) & $3.6(3.1-3.9)$ & 0.19 \\
\hline Uric acid & $6.7(5.6-7.86)$ & $6.7(5.6-7.9)$ & $6.4(5-7.1)$ & 0.19 \\
\hline Platelets & 217 (183-259) & $214(180-256)$ & 241 (213-293) & 0.00 \\
\hline Total cholesterol & $154.9(130-188.9)$ & $154.2(130-188.5)$ & $167(130-192)$ & 0.40 \\
\hline LDL cholesterol & $98.3(75-121.8)$ & $98(75.1-121.2)$ & 102 (74-129) & 0.45 \\
\hline HDL cholesterol & $34.4(29.7-40)$ & $34(29.3-39.1)$ & $38(31-48)$ & 0.00 \\
\hline STH & $1.4(0.7-2.8)$ & $1.4(0.8-2.8)$ & $1.7(0.9-3.6)$ & 0.24 \\
\hline
\end{tabular}

IQR: interquartile range; LDL: low-density lipoprotein; HDL: high-density lipoprotein; STH: stimulant thyroid hormone. STEMI: ST-segment elevation myocardial infarction.

Table 5. Comparison of the first medical contact time and total ischemic time in patients with STEMI

\begin{tabular}{|l|c|c|c|c|}
\hline Time $(\mathbf{m i n})$ & Total $(\mathbf{n}=\mathbf{3 4 0})$ Median (IOR) & PS $(\mathbf{n}=\mathbf{1 6 6})$ Median (IOR) & PCI (n= 174) Median (IOR) & $\mathbf{p}$ \\
\hline Total ischemic time & $320(205-599)$ & $347.5(200-600)$ & $310(205-557)$ & 0.52 \\
\hline First medical contact & $120(60-270)$ & $120(60-225)$ & $150(60-300)$ & 0.11 \\
\hline Door-to-needle time & - & $54(30-103)$ & - \\
\hline PS & - & $1440(600-2880)$ & - \\
\hline Door-to-device time & - & - & $72.5(60-95)$ & - \\
\hline
\end{tabular}

PS: pharmacoinvasive strategy; PCI: percutaneous coronary intervention; SD: standard deviation; IQR: interquartile range. STEMI: ST-segment elevation myocardial infarction.

hemoglobin, mean value in females was 7.7 (5.9-9.5)\%, and mean value in man was $6.1(5.6-7.6) \%(p=0.00)$ (Table 4). One hundred and sixty-six patients were taken to PS and 174 to $\mathrm{PCl}$. The distribution by gender was $87.1 \%$ of male and $12.9 \%$ of female (Table 5 ).
Total ischemic time in the female group was 360 (214-658) min, first medical contact time was 180 (75-325) $\mathrm{min}$, the door-to-needle time was $31 \mathrm{~min}$ (20-85), and the door-to-device time was 73 (65-93) $\mathrm{min}$. In-hospital stay was similar to the male patients and the 
Table 6. Gender difference in attention times for reperfusion, hospital stay, and LVEF in STEMI

\begin{tabular}{|l|c|c|c|c|}
\hline Time & Total $(\mathbf{n}=\mathbf{3 4 0})$ & Male $(\mathbf{n}=\mathbf{2 9 6})$ & Female $(\mathbf{n}=\mathbf{4 4})$ & $\mathbf{p}$ \\
\hline Total ischemic time (min) & $320(205-599)$ & $313.5(205-589.5)$ & $360(214-658)$ & 0.63 \\
\hline First medical contact $(\mathrm{min})$ & $120(60-270)$ & $120(60-247.5)$ & $180(75-325)$ & 0.08 \\
\hline Door-to-needle time $(\mathrm{min})$ & $54(30-103)$ & $60(30-110)$ & $31(20-85)$ & 0.09 \\
\hline Door-to-device time (min) & $72.5(60-95)$ & $71.5(60-96)$ & $73(65-93)$ & 0.56 \\
\hline Hospital stay & $6(3-9)$ & $6(3-9)$ & $5(3-10)$ & 0.68 \\
\hline Final LVEF & $46(39-54)$ & $45.9(38.5-54)$ & $50(40-57)$ & 0.21 \\
\hline
\end{tabular}

LVEF: left ventricular ejection fraction. STEMI: ST-segment elevation myocardial infarction.

Table 7. In-hospital mortality in patients with STEMI taken to PS versus $\mathrm{PCl}$

\begin{tabular}{|l|c|c|c|}
\hline Variable & ACP $\mathbf{n}(\%)$ & EFI $\mathbf{n}(\%)$ & Total $\mathbf{n}(\%)$ \\
\hline Survival & $163(93.7)$ & $157(94.6)$ & $320(94.1)$ \\
\hline Death & $11(6.3)$ & $9(5.4)$ & $20(5.9)$ \\
\hline
\end{tabular}

$\mathrm{p}=0.82$. PS: pharmacoinvasive strategy; PCl: percutaneous coronary intervention. STEMI: ST-segment elevation myocardial infarction.

Table 8. Gender differences in survival

\begin{tabular}{|l|c|c|}
\hline Variable & Male & Female \\
\hline Survival n (\%) & $280(94.6)$ & $40(90.9)$ \\
\hline Mortality n (\%) & $16(5.4)$ & $4(9.1)$ \\
\hline Total n & 296 & 44 \\
\hline
\end{tabular}

$p=0.25$.

left ventricular ejection fraction was $50 \%$ for the female group without differences against the male group (Table 6).

In-hospital mortality was seen in 11 patients (6.3\%) who underwent $\mathrm{PCl}$ and 9 patients (5.4\%) who underwent PS without statistical significance (Table 7). In-hospital mortality was seen in $9.1 \%$ of the female group, corresponding to 4 patients (Table 8). In the logistic regression models, factors associated with mortality in man were serum glucose $>180 \mathrm{mg} / \mathrm{dl}$ systolic arterial pressure $<90 \mathrm{mmHg}$ and a GRACE score above 126 points (Table 9). In the logistic regression model for risk factors associated with mortality in the female group, there were no predictors found (Table 10).
Table 9. Logistic regression model for mortality in male patients with STEMI

\begin{tabular}{|l|c|c|c|}
\hline Variable & OR & p & IC $95 \%$ \\
\hline Diabetes mellitus & 2.94 & 0.03 & $1.06-8.18$ \\
\hline Hypertension & 1.61 & 0.35 & $0.58-4.46$ \\
\hline Previous myocardial infarction & 3.55 & 0.03 & $1.06-11.88$ \\
\hline Elevation of C-reactive protein & 1.53 & 0.43 & $0.51-4.53$ \\
\hline Elevation of troponin I & 1.19 & 0.73 & $0.42-3.38$ \\
\hline Elevation of serum glucose $>180 \mathrm{mg} / \mathrm{dl}$ & 7.33 & 0.00 & $2.0-26.33$ \\
\hline Total ischemic time $>180 \mathrm{~min}$ & 2.86 & 0.04 & $1.01-8.11$ \\
\hline Systolic arterial pressure $<90 \mathrm{mmHg}$ & 13.19 & 0.00 & $2.03-85.41$ \\
\hline Diastolic arterial pressure $<60 \mathrm{mmHg}$ & 2.6 & 0.38 & $0.3-22.51$ \\
\hline GRACE score $>126$ & 4.8 & 0.00 & $1.61-14.23$ \\
\hline
\end{tabular}

OR: odds ratio. STEMI: ST-segment elevation myocardial infarction.

\section{Discussion}

Coronary artery disease in women has had little appreciation and has been left behind due to the higher prevalence of STEMI in man before the age of 50 . Our study was focused on the characterization of women who suffer STEMI, to determine demographic, clinical, and laboratory data, evaluation of attention times, and in-hospital mortality compared to man. In our study, the mean age of STEMI presentation in women is similar to other parts of the world. Furthermore, our study shows that comorbidities such as diabetes mellitus, systemic arterial hypertension, dyslipidemia, and obesity are similar to other trials. However, in comparison to men, women had higher prevalence of cigarette smoking and diabetes mellitus. 
Table 10. Logistic regression model for mortality in female patients with STEMI

\begin{tabular}{|l|c|c|c|}
\hline Variable & OR & p & IC (95\%) \\
\hline Diabetes mellitus & 0.73 & 0.77 & $0.09-5.78$ \\
\hline Hypertension & 0.66 & 0.70 & $0.08-5.22$ \\
\hline Active smoker & 1.57 & 0.71 & $0.14-17.42$ \\
\hline Elevation of C-reactive protein & 0.37 & 0.36 & $0.04-3.03$ \\
\hline Elevation of troponin I & 0.6 & 0.62 & $0.07-4.71$ \\
\hline Elevation of serum glucose $>180 \mathrm{mg} / \mathrm{dl}$ & 1.79 & 0.62 & $0.17-18.91$ \\
\hline Total ischemic time $>180 \mathrm{~min}$ & 0.45 & 0.50 & $0.04-4.72$ \\
\hline Systolic arterial pressure $<90 \mathrm{mmHg}$ & 13 & 0.09 & $0.64-263.91$ \\
\hline Diastolic arterial pressure $<60 \mathrm{mmHg}$ & 4.11 & 0.27 & $0.32-52.69$ \\
\hline GRACE score $>126$ & 2.71 & 0.40 & $0.25-29.36$ \\
\hline
\end{tabular}

OR: odds ratio. STEMI: ST-segment elevation myocardial infarction.

These two factors might explain why women have worst prognosis than man. Nevertheless, the logistic regression model did not show any association in the overall outcome, we cannot say that there is an association to mortality. We acknowledge that this might be because of the low size sample. Therefore, it is necessary to increase the sample to show statistical significance. As we confirm a low representation of women, we also confirm the fact that not finding predictors for mortality make it difficult to implement different medical treatment for the female group. About $94 \%$ of woman had Killip-Kimball Class I-II, without differences in comparison to man. Regarding the risk score scales, women had higher TIMI, GRACE, and CRUSADE scores with statistical significance but without association to mortality. Women with ischemic heart disease have worst outcome compared to $\operatorname{men}^{7,8}$.

Those women who have a STEMI before the age to 50 are 2 times more likely to die ${ }^{11}$. Some explanations of why women die more than man are as explained by Bowles, most women do not attribute their symptoms to a cardiovascular cause which delays medical attention. This is reflected in our study since the first medical contact was much longer for women, who took $180 \mathrm{~min}$ to arrive to a medical facility, in comparison to man who took 120 min, meaning a delay of 60 min which again is reflected in longer total ischemic times for women, with a mean time of $360 \mathrm{~min}$ in comparison to man who had $313.5 \mathrm{~min}$. Although we did not find a significant statistical difference in survival between genders, the proportion of female deaths was higher than men. This might be biased by the lack of representation of the female population.

\section{Conclusions}

Mortality in female patients who developed STEMI did not have statistical significance over men, although the proportion of female deaths was higher. They have more prevalence of diabetes mellitus, obesity, and cigarette smoking. The lack of statistical significance is probably due to the lack of representation.

The majority of women had Class Killip y Kimball I-II, have higher TIMI, GRACE, and CRUSADE scores than man, and have higher levels of NT proBNP and more serum glucose at admission than men. Most women have longer times for the first medical contact which is reflected in the higher total ischemic time.

One practical lesson for cardiologists and non cardiologists is that we should implement more registries where women are included and generate research guided by gender since the course and treatment of STEMI is different in each group. Redirecting the treatment can improve outcomes for women who have STEMI. We need more representation of women in trials regarding cardiovascular disease to identify possible associations that might have an impact in mortality.

\section{Conflicts of interest}

None.

\section{Ethical disclosures}

Protection of human and animal subjects. The authors declare that no experiments were performed on humans or animals for this study.

Confidentiality of data. The authors declare that they have followed the protocols of their work center on the publication of patient data.

Right to privacy and informed consent. The authors declare that no patient data appear in this article.

\section{References}

\footnotetext{
1. Naghavi M, Abajobir AA, Abbafati C, Abbas KM, Abd-Allah F, Abera SF, et al. Global, regional, and national age-sex specific mortality for 264 causes of death, 1980-2016: a systematic analysis for the global burden of disease study 2016. Lancet. 2017;390:1151-210.
} 
2. Aggarwal NR, Patel HN, Mehta LS, Sanghani RM, Lundberg GP Lewis SJ, et al. Sex differences in ischemic heart disease: advances, obstacles, and next steps. Circ Cardiovasc Qual Outcomes. 2018; 11:e004437.

3. La Peña J, Rodríguez-Ábrego G, Buitrón-Granados LV. Coronary heart disease morbidity and mortality trends at the instituto Mexicano del seguro social. An ecological study of trends. Arch Cardiol Mex. 2010;80: 242-8.

4. Mehta LS, Beckie TM, DeVon HA, Grines CL, Krumholz HM, Johnson MN, et al. Acute myocardial infarction in women: a scientific statement from the American heart association. Circulation. 2016;133:916-47.

5. Sharma K, Gulati M. Coronary artery disease in women: a 2013 update. Glob Heart. 2013:8:105-12.

6. Sánchez-Barriga JJ. Sánchez-barriga comportamiento de la mortalidad por cardiopatía isquémica en. Gac Méd Méx. 2009;145:375-82.

7. Jerjes-Sanchez C, Martinez-Sanchez C, Borrayo-Sanchez G, CarriIlo-Calvillo J, Juarez-Herrera U, Quintanilla-Gutierrez J. Third national registry of acute coronary syndromes (RENASICA III). Arch Cardiol Méx. 2015;85:207-14.
8. Martínez-Sanchez C, Borrayo G, Carrillo J, Juarez U, Quintanilla J, Jerjes-Sanchez C. Abordaje clínico y evolución hospitalaria en pacientes mexicanos con sindrome coronario agudo: el tercer registro nacional de síndromes coronarios agudos (RENASICA III). Arch Cardiol Mex. 2016:86:221-32.

9. Solorio S, Hernández-González MA, Rangel Abundis A, Alberto y MuriIlo-Ortiz B. Cardiopatía isquémica en mujeres mexicanas. Arch Cardiol Mex. 2017:77(3):226-23.

10. Bowles JR, McEwen MM, Rosenfeld AG. Acute myocardial infarction experience among Mexican American women. Hisp Health Care Int. 2018;16:62-9.

11. Saiso SG, González OS, Estrello PP, Mendoza MA, Contreras-Villaseñor A, Rodríguez-Zanella H. La Atención del Infarto Agudo al Miocardio en México. Estudio de Oferta y Demanda y Análisis Económico Exante de un Programa Nacional de Reducción de la Mortalidad por Infarto Agudo al Miocardio. Publicación Conjunta de la Secretaría de Salud, Banco Interamericano de Desarrollo e Instituto Nacional de Cardiologia Ignacio Chavez; 2017.

12. Baeza-Herrera LA, Araiza-Garaygordobil D, Gopar-Nieto R, Raymundo-Martínez GI, Loáisiga-Sáenz A, Villalobos-Flores A, et al. Evaluation of pharmacoinvasive strategy versus percutaneous coronary intervention in patients with acute myocardial infarction with ST segment elevation at the national institute of cardiology (PHASE-MX). Arch Cardiol Mex. 2020;90:158-62. 